ks. Bogustaw Kieżel

Archidiecezjalne Wyższe Seminarium Duchowne w Biatymstoku

\title{
Interreligious Dialogue of the Catholic Church With the Candomblé Communities in Brazil
}

\section{DIALOG MIĘDZYRELIGIJNY KOŚCIOŁA KATOLICKIEGO ZE WSPÓLNOTAMI CANDOMBLÉ W BRAZYLII}

Deklaracja Soboru Watykańskiego Drugiego, Nostra aetate, poświęcona w całości zagadnieniu relacji Kościoła katolickiego do religii niechrześcijańskich, ukazała nową postawę Kościoła wobec innych religii i określona została pojęciem „dialog". Kościół katolicki - we współczesnym, wielokulturowym społeczeństwie Brazylii - prowadzi dialog międzyreligijny z wieloma wspólnotami religijnymi, a wśród nich ze wspólnotami Candomblé, które swoje korzenie mają w wierzeniach pochodzenia afrykańskiego. W niniejszym artykule ukazano, w zarysie, zagadnienie dialogu międzyreligijnego Kościoła katolickiego ze wspólnotami religijnymi Candomblé w Brazylii. W pierwszej części wskazano na podstawy dialogu w nauczaniu Kościoła katolickiego oraz jego realizację w dokumentach Konferencji Episkopatu Brazylii. Następnie zarysowano problematykę dialogu międzyreligijnego w ujęciu teologii afroamerykańskiej oraz próby prowadzenia dialogu w obrębie wspólnot Candomblé. W ostatniej części opracowania wskazano na rolę mitologii w wierzeniach Jorubów z Nigerii jako wyzwanie w procesie prowadzenia dialogu religijnego Kościoła ze wspólnotami Candomblé w Brazylii.

Słowa kluczowe: Kościół katolicki, Candomblé, dialog międzyreligijny, religie afrobrazylijskie, mitologia, orisze, wierzenia Jorubów. 
Teologia dialogu

The declaration Nostra Aetate of the Second Vatican Council is dedicated to the relation of the Catholic Church to non - Christian religions. It is worth to take notice that the Council's teaching on the mystery of the Church as "the universal sacrament of salvation" (LG 48) has shown a new attitude of the Church toward non - Christian religions, which has taken the name of dialogue ${ }^{1}$. Raimon Panikkar mentions the very important suggestions of dialogue: "A religious dialogue must first of all be an authentic dialogue, without superiority, preconceptions, hidden motives or convictions on either side (...). Dialogue listens and observes, but it also speaks, corrects and is corrected; it aims at mutual understanding (...). Dialogue must proceed from the depths of my religious attitude to these same depths in my partner. In other words: I understand her - or try to - both from and within my faith, not by putting it aside" 2 .

In this paper we want to focus on the possibility and necessity of interreligious dialogue between the Catholic Church and the Candomble communities in Brazil. In the beginning we show the Catholic Church's teaching on interreligious dialogue and the achievement of interreligious dialogue in the documents of the National Conference of Bishops of Brazil. Next we try to present an overview of interreligious dialogue in the Afro-American theology and attempts of dialogue conducted by the Candomble communities. At the end we show an example of Yoruba mythology studies as a challenge for the interreligious dialogue between the Catholic Church and the Candomblé communities in Brazil.

\section{Interreligious Dialogue and its Purposes in the Teaching of the Catholic Church}

A term „dialogue” contains in itself a broad meaning and refers to the whole of human life and attitudes, to the various social and religious groups "in their appropriate relationship towards the other and different" "Interreligious dialogue, in the teaching of the Catholic

$1 \quad$ Secretariat for Non-Christians, The Attitude of the Church toward Followers of Other Religions: Reflections and Orientations on Dialogue and Mission, n. 2-3, www.cimer.org.au/documents/Dialogueand Mission1984.pdf, [10.01.2014], (The Attitude of the Church) .

2 R. Panikkar, The Intrareligious Dialogue, New York (NY) - Mahwah (NJ) 1999, p. 82.

3 M. Rusecki, Chrystologiczne podstawy dialogu międzyreligijnego, [in:] H. Zimoń (ed.), Dialog międzyreligijny, Lublin 2004, p. 33-35; Cf. M. Rusecki, Traktat o religii, Warszawa 2007, p. 510-512. 
Church, is understood as an attitude and relationship of the Church towards the non-Christian religions. Dialogue - according to the document of the Secretariat for Non-Christians The Attitude of the Church toward Followers of Other Religions - means "not only discussion, but also includes all positive and constructive interreligious relations with individuals and communities of other faiths which are directed at mutual understanding and enrichment"4. Interreligious dialogue plays an essential role in the evangelizing mission of the Church, because "mission deprived of this fundamental attitude of the dialogue does not correspond with the Christian mind"5. This dialogue is a fundamental part of the mission of the Church, which is called to collaborate in God's plan with her methods of presence, respect and love towards all persons ${ }^{6}$. The document of the Secretariat for Non-Christians recalls, that "the mission of the Church is carried out by means of that activity through which, in obedience to Christ's command and moved by the grace and love of the Holy Spirit, the Church makes itself fully present to all persons and peoples"7. Among the chief elements of the Church's mission there is a dialogue, "in which Christians meet the followers of other religious traditions in order to walk together toward truth and to work together in projects of common concerns. Finally, there is announcement and catechesis in which the Good News is proclaimed and its consequences for life and culture are analyzed. The totality of Christian mission embraces all these elements"8.

Principal themes in the interreligious dialogue - according to the teaching of the Catholic Church - are as follows: mutual acknowledgment, the issue of the truth, reciprocal conversion and building of the Kingdom of God. These topics constitute an essential base, on which interreligious dialogue partners find common goals for the realization of this dialogue. A basic goal of the dialogue is to come to better knowledge of other religions. "Christians - according to the document Dialogue and Proclamation - must be prepared to learn

4

The Attitude of the Church, n. 3. Cf. Pontifical Council for Interreligious Dialogue, Dialogue and Proclamation, n. 9, (Dialogue and Proclamation). http:// www.vatican.va/roman_curia/pontifical_councils/interelg/documents/rc_pc_interelg_doc_19051991_dialogue-and-proclamatio_en.html, [10.01.2014].

H. Waldenfels, O Bogu, Jezusie Chrystusie i Kościele - dzisiaj. Teologia fundamentalna $w$ kontekście czasów obecnych (Polish translation by A. Paciorek), Katowice 1993, p. 77. Cf. Nostra Aetate, n. 1.

The Attitude of the Church, n. 11. Cf. Ad Gentes, n. 5.

Ibidem, n. 13.

Teologia

dialogu

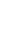

政


Teologia dialogu

and to receive from and through others the positive values of their traditions. Through dialogue they may be moved to give up ingrained prejudices, to revise preconceived ideas, and even sometimes to allow the understanding of their faith to be purified". Interreligious dialogue at its basis has also another objective: it is to bring about universal brotherhood, which religious communities in dialogue should pursue through the conversion of the heart for spiritual growth. Striving for the truth is the next aim in the interreligious dialogue, highlighted in the Church's documents. This aspect is essential in the dialogue, but at the same time it is one of the most difficult. Cultural pluralism causes "the truth is replaced by the decision of majority (...), because - as some people claim - the truth as a common, binding and accessible value for a person, cannot exist"10. Hence - as Joseph Ratzinger indicates "multitudes of cultures is a prove of their relativity"

Interreligious dialogue should be carried out - according to the documents of the Church - in the following form: the dialogue of life, the dialogue of actions, the dialogue of theological exchange and the dialogue of religious experience ${ }^{12}$. Interreligious dialogue in its basic dimensions becomes always an intercultural dialogue. Therefore, it can also support all kinds of efforts for the inculturation process of the Gospel and to make the Church be rooted in the various human cultures and nations ${ }^{13}$. To conduct this dialogue is an essential part in the Church's mission work, since it contributes to better mutual understanding, acknowledgment and enrichment ${ }^{14}$. The Church, as a depositor and guardian of the Revelation, is "to discover and acknowledge the signs of Christ's presence and of the working of the Spirit, as well as to examine more deeply her own identity and to bear witness to the fullness of Revelation (...)"15.

Dialogue and Proclamation, n. 49.

J. Ratzinger, Wiara - prawda - tolerancja. Chrześcijaństwo a religie świata (Polish translation by R. Zajączkowski), Kielce 2004, p. 59.

Ibidem.

Cf.: The Attitude of the Church, n. 28-35; Dialogue and Proclamation, n. 42.

On this issue see: L. J. Luzbetak, The Church and Cultures. New Perspectives in Missiological Anthropology, Maryknoll, New York 1988, chapters: V and VI; A. Shorter, Toward a Theology of Inculturation, Maryknoll, New York 1988, p. 241-271.

Redemptoris Missio, n. 55.

Ibidem, n. 56. 


\section{Purposes and Objectives of Interreligious Dialogue in the Documents of the National Conference of Bishops of Brazil}

In the documents of the National Conference of Bishops of Brazil, the terms: "religious dialogue" and "interreligious dialogue" are used alternatively. A concept of interreligious dialogue is presented according to the criteria pointed out by the Church's Magisterium ${ }^{16}$. Teologia The above mentioned documents include in the process of interreligious dialogue two of its essential aspects: 1) the dialogue between religions and 2) the dialogue between cultures ${ }^{17}$. The bishops show the good will and openness of the Catholic Church to get involved in the interreligious dialogue with all those, who believe in God, with the members of various religions in Brazil (religions of the indigenous people and Afro-Brazilians) as well as with all the people of good will, while underlining that the dialogue may contribute to the full growth of a person and promote the peace in the Brazilian society as well as in the whole world ${ }^{18}$.

Interreligious dialogue in the Brazilian and Latin-American context is to accomplish an essential task: to guard "the substance of various indigenous cultures trying to uncover in them genuine values, in which the Church finds the presence of semina verbi" ${ }^{\prime \prime}$. Within the framework of tasks for interreligious dialogue, the Bishops of Brazil include also protection, better appreciation and promotion of the Afro-Brazilian and Afro-American cultural and religious traditions, while taking into consideration the care for the closer relationship

16 Conferência Nacional dos Bispos do Brasil, $12^{\circ}$ Plano Bienal de Pastoral dos Organismos Nacionais (1993-1994), Programa 5 (Orientações comuns para a dimensão ecumênica, o diálogo inter-religioso e o diálogo com não-crentes), http:// www.cnbb.org.br, [12.01.2014], (CNBB).

17 CNBB, Diretrizes Gerais da Ação Evangelizadora (1995-1998), n. 207, http:// www.cnbb.org.br, [12.01.2014]. Cf. CNBB, Diretrizes Gerais da Ação Pastoral (1983-1986), n. 6, http://www.cnbb.org.br, [12.01.2014].The bishops recall that, it is essential for evangelization "not to carry it out in a decorative way (...), but to go deep to the very roots of the human culture and cultures in general". This attitude is confirmed by John Paul II: "Una fede che non si è fatta cultura è una fede che non è stata pienamente recepita, non è stata interamente pensata, non è stata fedelmente vissuta", [in:] Commisione Teologica Internazionale, Il cristianesimo e le religioni (1997), Documenti 1969-2004, (Prefazione: card. W. J. Levada), Bologna 2010 (seconda edizione), n. 26, p. 554.

18 CNBB, Evangelização e missão profética da Igreja (2005), n. 2.3.1, São Paulo 2005, p. 62-63.

$19 \quad$ CNBB, Diretrizes Gerais da Ação Evangelizadora (1995-1998), op. cit., n. 212. 
of the Catholic Church with the followers of Afro-Brazilian religions. This dimension of the interreligious dialogue becomes a part of the inculturation process of the faith, "that cannot be separated from the encounter with other religions" 20

The Catholic Bishops of Brazil, having in mind the preferential option for the poor, point out some important directions in the exercising of interreligious dialogue ${ }^{21}$. The basic task in this work is to stand up for the dignity of a person, in particular in the Brazilian context especially, for the poor and socially marginalized. The documents of the Bishops of Brazil point out some areas, where interreligious and ecumenical dialogue needs to be conducted. First of all - according to the documents of the Episcopate Conference of Brazil - it should reach communities of the followers of Judaism and Islam. Other groups, the Church in Brazil considers as important in this dialogue, are Christian communities (in particular Pentecostals), Afro-Brazilian religious communities ${ }^{22}$ as well as individual leaders of Umbanda cult centers, Candomblé and spiritistic groups. Special attention in this endeavour should be paid to the different variations of spiritism and religious groups named as "sects"23. Another challenge for interreligious dialogue - according to the documents of the Episcopate of Brazil - is a constantly growing group of non-believers and those "without any religion" 24 . The dialogue with this groups of the society - as the bishops

$20 \quad$ Commisione Teologica Internazionale, op. cit., n. 26, p. 554.

CNBB, $12^{\circ}$ Plano Bienal de Pastoral dos Organismos Nacionais (1993-1994), op. cit., Programa 5. (Orientações comuns para a dimensão ecumênica,o diálogo inter-religioso e o diálogo com não-crentes).

CNBB, 5. Plano Bienal dos Organismos Nacionais (1979-1980), Programa 5, n. 4.2, http://www.cnbb.org.br, [12.01.2014].

CNBB, Diretrizes Gerais da Ação Pastoral (1979-1982), n. 83; n. 95, http://www. cnbb.org.br, [12.01.2014].

CNBB, $12^{\circ}$ Plano Bienal de Pastoral dos Organismos Nacionais (1993-1994), op. cit., Programa 5. Brazilian bishops discribe this situation in the following way: "Without any doubt, there are persons in Brazil, who practice certain forms of atheism (practical and theoretical atheism, agnosticism, religious indifferentism etc.), however above all it is visible in the spirit of the organized view of the world or in the proposal of ideologies and other specific trends in the cultural life of the country. On the other hand, there exists a virtually spontanious rejection of any kind of declared form of formal atheism, what effects that a declared atheists finds it difficult to be socially and legally recognized". Original text: "Sem dúvida, existem no Brasil muitas pessoas que aderem a uma ou outra forma de ateísmo (ateísmo teórico e prático, agnosticismo, indiferentismo diante da questão religiosa etc.), mas é antes uma atitude de espírito do que um princípio organizativo de uma visão do mundo, ou postulado ideológico que regem as manifestações de determinadas correntes na vida cultural do país. Por outro 
notice - does not come easily. They also are of essential challenge for the evangelization in Brazil.

In order to improve a successful conducting of the interreligious dialogue, the National Conference of the Bishops of Brazil conducts professional trainings for the persons involved in this work, namely for priests, seminarians as well as religious and lay people engaged in the ecumenical and interreligious movement ${ }^{25}$. The Episcopate Conference of Brazil, through the Committee for the Catholic - Jewish Dialogue, dialogu organizes meetings with the Jewish communities in Brazil as well as with the representatives of Islam. The Catholic Church in Brazil through its special body: Mission Council for the Indigenous People (CIMI - Conselho Indigena Missionário), carries out interreligious dialogue with the representatives of the indigenous religions, and within a framework of the Committee for the Missions, maintains contacts with the representatives of the Afro-Brazilian religions.

\section{Interreligious Dialogue in the Candomblé Communities}

Let's start with presenting, in outline, the situation that arisen in context during the II World Conference taking place in Salvador (Brazil, capital of the State of Bahia, July 17-23, 1983) on the subject "Tradition and Culture of Orishas". The result of this conference is a document (so-called manifest) signed by leaders of the Candomblé communities, in which above else presented was decision that breaks away from syncretism and - at the same time - it was observed that Candomble is considered a true religion, independent of Catholicism. It was also denied sect dimension and primitive animism ${ }^{26}$.

Mother Stella do Opô Afonjá, yalorisha from Salvador, pointed out an independence of two cults:

Catholic saints and African orishas as well as the fact that orishas cult has its roots in African religions brought to Brazil by the African slaves, and independently of the Catholicism, it existed as a religion: images and sculptures of the Catholic saints have their value. We are not planning to break away from the faith - ie. - in Saint Barbara. She is, no doubt, a lofty spirit. However, we know that Iansa a is a different energy and is not Saint Barbara (...); it has nothing in common, for example, to offer

lado, há uma rejeição quase espontânea no povo por toda declaração formal de ateísmo, o que faz com que o ateu declarado e confesso tenha dificuldade de fazer-se socialmente reconhecido e legitimado". 
at the feet of Saint Barbara a sacred food dedicated to Iansã. That has no sense. This food is dedicated to Iansã, that is absolutely a different energy (dimension of worship) from the cult of Saint Barbara. This break away from Catholicism is not supposed to be seen as a schism, therefore, with the need of abandoning a Catholic faith. The Candomble - as the religion of orishas - is not incompatible with the Catholic religion" ${ }^{27}$.

Mother Stella do Opô Afonjá also stated at this conference: "It depends on everyone's consciousness if the person knows who is Ogum, and that doesn't mean that to believe in Saint Anthony, because - as I said - these are different energies"28. The leaders of the Candomblé communities, participating in this conference, asked that the orishas cult be respected. The perspective of a great importance of dialogue in the life of the Candomble communities with the Catholic Church remind the words of Mother Stella do Opô Afonjá: "The Candomblé has to be respected not as a folklore but as a religion" 29 .

The request of members of Afro-Brazilian religions to distance their cults from Catholic religious practices caused heated discussion on the religious syncretism. Archbishop of Salvador, cardinal Avelar Brandão Vilela, in his pastoral letter (July 31, 1983) said: 'With absolute peace and understanding I accepted decision of leaders of the Candomble as to rejection of religious syncretism, demonstration of autonomy and internal logic deserving of the mature socially organism, conscious of its status (...). If Candomblé regards itself as a true religion, without any reference to popular Catholicism and touristic or folkloristic dimensions, this problem should be considered closed'30. The Archbishop of Salvador drew attention to the necessity of revision of the liturgical rites in Candomblé, especially so-called lavagem do Senhor Bomfim (taking place in January).

\section{Dialogue in the Afro-American Theology ${ }^{31}$}

A basic form of ecumenism is "popular ecumenism". This form of ecumenism was born in the Ecclesiastical Basic Communities

$27 \quad$ Ibidem, p. 73.

28 Ibidem.

29 J. G. Consorte, Em torno de um manifesto de ialorixás baianas contra o sincretismo, [in:] C. Caroso, J. Bacelar (ed.), op. cit, p. 74.

30 C. Caroso, J. Bacelar, op. cit., p. 77.

31 On interreligious dialogue in Brazilian context see: R. Drubi, O diálogo interreligioso, [in:] N. de Sousa (ed.), Temas de teologia latino-americana, São Paulo 2007, p. 211-229. 
(Comunidades Eclesiais de Base - CEBs) ${ }^{32}$. The main purpose was to serve all community and concern for better future of the poor. The biblical reflections helped all members of those communities to live and share the faith in the same God. Another concept of ecumenism is "macro - ecumenism" which was born during the Conference of Assembly of the People of God (Assembleia do Povo de Deus) in Quito $(1992)^{33}$. The final document of this Conference defined the macro ecumenism "as a true ecumenism and has the same dimension as dialogu the People of God. No one religion can take this exclusively for itself because we are all the People of God"34.

Ecumenical Association of the Third World Theologians (EATWOT's) organized in Duque de Caxias (state of Rio de Janeiro) $1^{\text {st }}$ Consultation on Negro Culture and Theology in Latin America. Conference took place July 8-12, 1985 and had a motto: 'Negro Identity and Religion'. Conference brought together participants from eight countries. In exceptional way the Conference pointed out a problem of religious syncretism $^{35}$. It says among other things: "We propose that the term 'syncretism' either be set aside in its traditional use or be redefined in relation to the African religions in Latin America and Caribbean [for] most the time it is a superficial concept besides being used by the extraneous observer to refuse any kind of autonomy to African religions in the Americas and in this way to avert any sort of ecumenical projects with Christianity" ${ }^{36}$. The final document, according to Ecumenical Association of the Third World Theologians, reaffirmed the necessity of "a new ecumenical approach which recognizes in all religions the

32 H. Frisotti, Passos no dialogo: Igreja catolica e religiões afro-brasileiras, São Paulo 1996, p. 55-56.

33 E. Valle, Macroecumenismo e diálogo inter-religioso como perspectiva de renovação católica, www.pucsp.br/rever/rv2_2003/p_valle.pdf, [10.01.2014].

34 Manifesto do Primeiro Encontro da Assembleia do Povo de Deus, Quito, September 18, 1992, [in:] H. Frisotti, op. cit., p. 56-57.

35 I Consulta sobre Cultura Negra e Teologia na América Latina, Duque de Caxias, R. J., July 8-12, 1985, [in:] ASETT, Identidade negra e religião: consulta sobre cultura negra e teologia na América Latina, Rio de Janeiro - São Bernardo 1986, p. 36 .

$36 \quad$ ASETT, Identidade negra e religião: Consulta sobre Cultura Negra e Teologia na America Latina, Rio de Janeiro 1986, p. 47. Cf. A. M. L. Soares, Catholic Theology Dilemmas in the Face of Afro-Brazilian Religious Syncretism, "Journal of Theology \& Culture" 5/2 (2006), p. 10, http://ciberteologia.paulinas.org.br/ ciberteologiaen/wp-content/uploads/2009/08/CatholicTheologyDilemmas.pdf [15.01.2014]. 
Teologia dialogu

dimension of evolution and complementation throughout history" 37 . During the $2^{\text {nd }}$ Ecumenical Consultation on the Afro-American and Caribbean Theology and Cultures the participants discussed the subject `Ecumenism in the Negro Communities of Faith ${ }^{` 38}$. Antônio A. da Silva who writes that it is necessary to overcome the difficulties and to search for Afro-religious dialogue ${ }^{39}$. Afonso M. L. Soares and Antonio A. da Silva show the main subjects for this dialogue: ecumenism, macro - ecumenism (integral ecumenism) and also mention the enculturation (...) as "a practice in which priority is given to people with its cultures that certainly do not subjugate the Gospel but integrate its message in life itself" 40 .

It is worth to take notice of importance of interreligious dialogue in the life of father François de l'Espinay and bishop José Maria Pires (Dom Zumbi). Father François de l'Espinay (died December 18, 1985) was a delegate of the Commission of French Episcopate in Latin America (CEFAL). He lived in Brazil in the city of Salvador since 1974. He joined one of centers (terreiros) of Candomblé and later was chosen to the Council of Shangó. I would like to make a note of the aspect of experience of faith in l'Espinay's life ${ }^{41}$. In his faith, the meeting with Unknown was very important. The life in the Candomble community confirmed his beliefs that faith has to be shared with other people ${ }^{42}$. The faith in God experienced in the community seems to be an interesting and important aspect of the dialog: Church - Candomblé. Let's remember what l'Espinay said about dialogue: "Dialogue is possible only when you say: Come with me and we will walk together (...). To respect Candomble is to accept from the Negro people all religious heritage, which better helps us to get to know who is God, Jesus Christ and Church" ${ }^{43}$. Bishop José Maria Pires is one of the Brazilian negro bishops who revealed the importance of the heritage in Christian faith as well as in the faith of Afro-Brazilian religions. Bishop J. M. Pires

$37 \quad$ Ibidem.

ATABAQUE - ASETT, Teologia afro-americana: II consulta ecumênica de teologia e culturas afro-americanas e caribenha, São Paulo 1997, p. 157-168.

A. A. da Silva, Elementos e pressupostos da reflexão a partir das comunidades negras - Brasil, [in:] ATABAQUE - ASETT, Teologia afro-americana, op. cit., p. 49-72.

A. A. da Silva, op. cit., p. 71. Cf. A. M. L. Soares, op. cit., p. 11. Eclesiástica Brasileira” 47/187(1987), p. 639-650.

H. Frisotti, op. cit., p. 65. 
emphasized important aspects in the dialogue between Christianity and Candomblé: cult of the Ancestors and cult of the Saints. In 1992 he said: "Pretos Velhos (...), the symbol of our immortality, remind us that our ancestors are alive, present and they protect us" ${ }^{44}$. Bishop José Maria Pires, as well as Father François de l'Espinay, show us interesting and important aspects of the dialogue between the Church and the Candomble communities and also invite us to continue that dialogue in spite of many difficulties.

\section{Yoruba Mythology Studies as an Objective and Challenge for the Dialogue to Succeed}

Yoruba religions, in Africa as well as in Latin America, are rich in myths ${ }^{45}$. Myths are the sacral histories which explain the beginnings and origin of "things and human beings" 46 , or - as Mircea Eliade defines - "Myth is a history about that what happened in illo tempore, and an account what was done by Gods and Heroes at the beginning of times (...). Myth foretells a revelation of new cosmic 'situation' or event that took place at the Beginning of Times" ${ }^{\text {" }}$. In the modern World „we have substituted different modes of interpretation for the stories, viewing them largely as keys to self - improvement and spiritual growth (...). It might be more accurate to call these stories 'traditions of origins', leaving out the word 'myth', for that phrase captures the defining criteria: the stories describe cultural origins for the peoples involved, and they are 'traditional' - meaning that they have been handed down from one generation to another, although always with changes and adaptations to keep them relevant to their contemporary audiences" ${ }^{48}$.

$44 \quad$ Ibidem, p. 66.

45 On Yoruba mythology see: J. Beniste, Mitos Yorubás. O Outro Lado do Conhecimento, Rio de Janeiro 2006; R. Prandi, Mitologia dos Orixás, São Paulo 2001; S. Belcher (ed.), African Myths of Origin, London 2005, p. 97-99.

S. Belcher, op. cit., p. xiii.

47 M. Eliade, Sacrum i profanum. O istocie religijności, (Polish translation by R. Reszke), Warszawa 1999, p. 78. Cf.: M. Eliade, Aspekty mitu (Polish translation by P. Mrówczyński), Warszawa 1998, p. 11-12; Jan Paweł II, Mężczyzna i niewiasta stworzyt ich. Odkupienie ciata a sakramentalność matżństwa, Lublin 2008, p. 13-14; H. Blumenger, Praca nad mitem (Polish translation by K. Najdek, M. Herer, Z. Zwoliński), Warszawa 2009, p. 3-56.

S. Belcher, op. cit., p. xiv. 
In Nigeria they are called od $u^{49}$, in Cuba myths are named appata$k i^{50}$. The word "Ifá" in Yoruba language means: scratch, paw, wipe. In religious meaning, that interests us, it pertains to writing signs odù ${ }^{51}$ on ashes, scattered on a sacral tray that serves for foretelling a prophecy Ifá ${ }^{52}$. Ifá - according to Yorubas - is a holy city in which took place the birth of humanity ${ }^{53}$. In general understanding "Ifá" means: 1) in Yoruba beliefs from Nigeria: deity of omen, wisdom and prediction (Òrúnmìlà) ${ }^{54}$, as well as whole system of divination. Ifá, in these beliefs, is defined as "a witness of human fate", that accompanies deity Olórun in the process of establishing of fate and future of a human being, 2) the name of foretelling system (oracle) in Yoruba beliefs, in which babaláwo (priest of Ifá-Òrúnmilà $)^{55}$ realizes the practices of foretelling with the help of following means: a) òpèle ${ }^{56}$ - special, little chain made of metal or woven from cotton, b) ìbò ${ }^{57}$ - special instrument used by babaláwo in foretelling system, c) ikin - shells of palm nuts called òpè ifá, $d$ ) búzios (in Yoruba: ówó eyo) - see shells performing a sacral function in the Ifá system, also called kauris ${ }^{58}$. Ifá, according to Yoruba mythology, returning to heaven left on earth ikin as the most important source of communication between the people and If $f^{59}$.

The divination practices are based on so-called Ifá divination system, also called "literary Ifá corps" or "odù corps (Ifá nlánlá)"60. This system provides the main element of integration in Yoruba community

49 S. Sàlámì [King], R. I. Ribeiro, Exu e a ordem do universo, São Paulo 2011, p. 448.

O. O. Espín, A fé do povo, São Paulo 2000, p. 269.

S. Sàlámì [King], Matriz iorubá de práticas divinatórias nos paises da diáspora africana, [in:] E. Pinto (ed.), Religiões, Tolerância e Igualdade no Espaço da Diversidade (exclusão e inclusão social, étnica e de gênero), vol. 1, São Paulo 2004, p. 42.

J. Beniste, Òrun, Àiyé: o encontro de dois mundos, Rio de Janeiro 2000, p. 99.

S. Piłaszewicz, Religie i mitologia Czarnej Afryki. Przeglad encyklopedyczny, Warszawa 2002, p. 110.

S. Sàlámì [King], R. I. Ribeiro, op. cit., p. 464.

Ibidem, p. 419; S. Piłaszewicz, op. cit., p. 57.

Ibidem, p. 463.

Ibidem, p. 433.

S. Piłaszewicz, op. cit., p. 110. Cf.: S. Sàlámì [King], op. cit., p. 39; J. Beniste, Jogo de búzios. Um Encontro com o Desconhecido (5. ed.), Rio de Janeiro 1999, p. 98-99. 
and establishes the rules for integrating certain individuals in social and religious life. The literary corps creates also a vision of the system that regulates an organization of whole existing reality and its interpretation. Because of that Ifá-Òrúnmìlà (deity of wisdom) occupies an exceptional and privileged place in the pantheon of deities.

The Ifá divination system consists of 256 so-called odù, grouped in 16 bigger odù (oju odù) and 240 smaller odù (omo odù or àmúlù odù), which create in combination $(16 \times 16 \times 16) 4096$ poems (itàn) ${ }^{61}$. The smaller odù is devided into 12 sections, so-called apola, which - in the process of Ifá rituals - are changing respectively their number ${ }^{62}$. The term "odù" also defines the position (order) of shells in the ritual jogo de buzios. Odù, grouped in chapters called Ésè, are made of stories, legends, mythological narratives ${ }^{63}$. Odù perform the function of documentation and passing on historical events. They preserve the collection of norms and behaviors appropriate to given community and spread them in this community. Babaláwo (in Brazil: babalorisha or yalorisha), in the process of initiation to community - via Ifá system - first of all tries to find odù of birth of given adept (ìyàwó) ${ }^{64}$, who will honor in his life a given orisha. The orisha of birth directs a believer to different dimensions of his life, helping also in preserving the moral norms (ìwà) ${ }^{65}$. If odù plays a main role in divination system, then Ésè are responsible in it for the poetic forms directing to the system of learning, history, geography, religion, music, philosophy and are the main collection of moral norms presented in metaphorical way.

The Ifá divination system, according to Yoruba mythology, contains following pantheon of deities: Eji Ogbe / Oyeku Meji / Iwori Meji / Odi Meji / Irosun Meji / Owonrin Meji / Obara Meji / Okanran Meji / Ogunda Meji / Osa Meji / Ika Meji / Otuurupon Meji Otuua Meji / Irete Meji / Ose

\footnotetext{
Ibidem.

62 S. Sàlámì [King], op. cit., p. 38.

63 S. Sàlámì [King], R. I. Ribeiro, op.cit., p. 228. Cf. J. Beniste, Òrun, Àiyé, op. cit., p. 111.

64 S. Sàlámì [King], R. I. Ribeiro, op.cit., p. 443; N. Lopes, Enciclopédia Brasileira da Diáspora Africana, São Paulo 2004, p. 333.

65 O. Gudolle Cacciatore, Dicionário de Cultos Afro-Brasileiros (3. edição revista), Rio de Janeiro 1977, p. 116-117; S. Sàlámì [King], R. I. Ribeiro, op. cit, p. 441: „İwà - é um conceito iorubá que reune o que denominamos caráter e personalidade. Inclui attitudes, posturas, condutas, comportamentos, formas de proceder, formas de reagir ao que se apresenta, na medida em que attitudes e comportamentos revelam a dinâmica estabelecida entre a personalidade e o carater", Ibidem, p. 172.
} 
Meji /Ofun Meji ${ }^{66}$. It is worth to take notice that existing hierarchy of respective deities can undergo changes based on the needs in given ritual of Ifá. The basic means in the Ifá divination system are: opele, ikin, ibo and búzios (respectively: little chain, palm nuts, question and sea shell) ${ }^{67}$.

In Brazil widely used system of divination is called jogo de búzios

Teologia dialogu (throwing sea shells) ${ }^{68}$. Babalorisha or yalorisha, performing throws of sea shells, observes open surfaces of individual shells (búzios). For each number of shells (1 to 16) - in ascending order - responds given odù. In Brazil divination system occurs in slightly changed form as the number of used sacred shells (búzios) ${ }^{69}$. Even though the norm in the divination system is to use 16 shells, yet used are $7,12,3$, or 21 shells, which are stored in the sacred vessel called kòlòbo ${ }^{70}$. This vessel has its own place in so called assentamento of orishas, that is the sacred place used to keep the àse of orishas with exception of orisha Ėsú, who always has a separate assentamento (sacred place).

The sacred divination of Ifá in Brazil, regardless of the number of shells applied, is called Dilogun or Erindilogun, which in Yoruba language means: number $16^{71}$. The main orisha, in Dilogun divination ritual, is orisha Ifá. The orisha - mediating, obtaining the answer is orisha Èsú. The rituals in jogo de búzios in Brazil don't have specific rules as to the place. Roger Bastide and Pierre Verger confirm that ritual cannot be performed in the place of babaláwo, however in Candomble centers (terreiros) most often it is done in suitable place, sometimes in priest's bedroom ${ }^{72}$. The orishas, in jogo de búzios, transmit an information from the oracle odú. Through a given arrangement of the shells is read a characteristic of respective orisha ${ }^{73}$. This system also plays a fundamental role in the process of initiation of respective

$66 \quad$ S. Sàlámì [King], op. cit., p. 37.

67 O. Gudolle Cacciatore, op. cit., p. 70; p. 194; N. Lopes, op. cit., p. 334; p. 337.

On Jogo de búzios divination system in Brazil see: R. Bastide, P. Verger, Contribuição ao Estudo da Adivinhação no Salvador (Bahia), "Revista do Museu Paulista" 8 (1953), p. 357-380; J. Braga, O jogo de búzios. Um estudo da adivinhação no Candomblé, São Paulo 1988; R. Ribeiro, Cultos afro-brasileiros do Recife. Um estudo de ajustamento social, Recife 1978, p. 87-102.

J. Braga, O jogo de búzios. Um estudo da adivinhação no Candomblé, São Paulo 1988, p. 85-86.

$70 \quad$ Ibidem, p. 86 ; O. Gudolle Cacciatore, op. cit., p. 158.

$71 \quad$ O. Gudolle Cacciatore, op. cit., p. 104.

72 R. Bastide, P. Verger, op. cit., p. 368.

73 J. Braga, op. cit., p. 98-107. Cf. R. Ribeiro, op. cit., p. 87-102. 
ìyàwó to religious community, who in jogo de búzios is assigned to the respective orisha which leads the adept in his daily life.

An important element in jogo de búzios system is also making a sacrifice $(e b o)^{74}$. The person consulted in ritual jogo de búzios - in compliance with the priest's recommendation - has to make so many offerings (ebo), as many problems were consulted in given jogo de buizios. It is worth to take notice that in historical process of forming Teologia Afro-Brazilian religions, it did not form the status of babaláwo in dialogu a priest's hierarchy, but only the status of babalorisha and yalorisha. That makes - in contrast to the Yoruba religious system - a significant difference in considering preparation for managing the individual cult centers. A time of preparation to perform the function of babaláwo, among the Yorubas, is $12-16$ years ${ }^{75}$.

The excellent example of the myth exegesis has been written by Orlando O. Espin in "Iroko and Ara-Kolé: an exegetical commentary on Yoruba - Lucumi myth: Contribution to the dialogue with Afro-Americans religions"76. The sacred tale (appataki) "Iroko and Ará-Kolé" shows the relations which take place between Heaven and Earth (in Yoruba: Òrun and Àiyé). In this tale arises the question as to the role of evil, sin and forgiveness. This myth indicates an answer, who is God (Olórun). In the Yoruba beliefs God is a "Being distant" from the Earth through his holiness and perfection as well as his omnipotence, because he does not have to worry about human beings on the Earth. For the purpose of leading the live of people, Olórun sends the orishas to the Earth . Even though he is distant from the Earth, Olórun accepts the gifts and sacrifices made for him. The God of Yorubas is the hidden God (Deus absconditus). The myth "Iroko and Ará-Kolé" shows that measure of secretiveness of God, his inconceivableness, in which God is hidden from the eyes of Yoruba people. The Yoruba myths show the depth of their religiosity; point out the need of mutual understanding; underline a necessity of God's forgiveness, his wisdom as well as his solidarity and compassion for every human being. The sacred tales, such as "Iroko and Ará-Kolé", remind the Old Testament prophecies of Messiah, however they differ significantly from the Christian doctrine of salvation in Jesus Christ. An example of "Iroko and Ará-Kolé" myth shows understanding of the faith in Yoruba comprehension. The im-

\footnotetext{
74 S. Sàlámì [King], R. I. Ribeiro, op. cit, p. 425.

75 Private information from Síkírù Sàlámì [King], Nigerian babalirisha, chief of the Traditional Yoruba Religion Center Oduduwa in Mongaguá (São Paulo state, Brazil).

$76 \quad$ O. O. Espín, op. cit., p. 277-306.
} 
portance of sacred tales in Yoruba beliefs underlines the necessity of intensified studies on the theology of religions, which may contribute to development of interreligious dialogue between the Catholic Church and the Candomblé communities in Brazil.

Teologia dialogu

\section{Conclusion}

Presented above, in outline, the question of interreligious dialogue of the Catholic Church with the Candomble communities in Brazil represents the important challenge for the both communities. Reciprocal recognition of the religious, cultural and historical values constitutes an essential task that stands before the Catholic Church and the Candomble communities. It appears that in this work the important role should play the theology of religion in the Latin-American context. We may agree with J. Deotis Roberts' opinion: "Black Americans share the human misery and ancestry with most Third World peoples (...). A great challenge faces black theologians and churches at this time in history. The objective of this discussion has been to provide some perspective on dialogue and ministry toward the fulfillment of this mission (...). One of the important roles we must assume is to make sure that the African/Afro-American cultural and religious experience is included in interreligious dialogue" 77 .

Although "many theological circles have not discovered the riches and magnitude of Yoruba faith and it seems they haven't even come to understand such faith as a 'religion` (and more precisely, non-Christian religion)" 78 , we hope that this study will help us to discover in theology something that was obvious for millions of Latin-Americans for more than two centuries. The interreligious dialogue should be a priority for the Catholic Church and the Candomble communities in Brazil. Overcoming prejudices this dialogue can be accepted as a necessary element of life in the Latin-American continent. In spite of the very difficult and painful history of the Brazilians we hope the dialogue is the best way for the harmony of life and faith for both communities: the Church and the Candomble and can be a symbol of an open door to the house of the only God.

Key words: Catholic Church, Candomblé, interreligious dialogue, Afro-Brazilian religions, mythology, orishas, Yoruba beliefs.

77 J.D.Roberts, Modelsfor Christian DiscipleshipamidReligious Pluralism:A Panel Discussion, [in:] G. Anderson, Th. F. Stronsky, Christ's Lordship, Maryknoll (NY) 1981, p. 176.

$78 \quad$ O. O. Espín, op. cit., p. 286. 